\title{
Antitumor Activities of Iodoacetate and Dimethylsulphoxide Against Solid Ehrlich Carcinoma Growth in Mice
}

\author{
FAWZIA A FAHIM*, AMR Y ESMAT, ESSAM A MADY and EMAD K IBRAHIM \\ * Department of Biochemistry, Faculty of Science, Ain Shams University, Abbassia, Cairo, Egypt
}

\begin{abstract}
Treatment of tumor-bearing mice with $\mathrm{LD}_{12.5}$ values of iodoacetate; IAA (1.84 mg/100g b.w.) and/or dimethylsulphoxide; DMSO (350 mg/ 100g b.w.) significantly increased the cumulative mean survival time and percentage of survivors and reduced the mean tumor weight, compared to tumor-bearing controls, however, a more pronounced effect is recorded in the combined treatment. Also, an increase in the life span (ILS\%) and tumor growth inhibition ratio (T/C\%) are reported and amounted to 145.78 and $43.80 \%, 195.54$ and $61.30 \%$ and 220.77 and $78.40 \%$ in IAA, DMSO and combined-treated groups, respectively. Results obtained from biochemical studies reveal that a single IAA treatment of tumor-bearing mice significantly increased the levels of plasma lactate dehydrogenase (LDH) activity, while it also significantly decreased the levels of plasma glucose and liver total protein, RNA and DNA, compared to normal controls. On the other hand, a single DMSO treatment significantly elevated the activities of blood antioxidant enzymes, i.e. glutathione peroxidase $\left(\mathrm{GP}_{\mathrm{x}}\right)$ and glucose-6-phosphate dehydrogenase $(\mathrm{G} 6 \mathrm{PDH})$ and decreased the liver RNA and DNA levels. Combined treatment increased significantly the levels of plasma LDH and erythrocytes G6PDH activities, as well as liver glycogen, and in contrast it decreased the levels of liver total protein, RNA and DNA, compared to normal controls.
\end{abstract}

Key terms: antioxidant enzymes, carbohydrate metabolism dimethylsulphoxide, iodoacetate, solid Ehrlich carcinoma

\section{INTRODUCTION}

In cancer cells, glycolysis is the main process involved in the production of ATP caused by hypoxia, which results from defective or insufficient tissue vasculature (Kairento et al., 1985). The pentose phosphate pathway (PPP) is also important in the tumor proliferation process because of its role in supplying tumor cells with pentoses, reduced $\mathrm{NADP}^{+}$and carbons for the intracellular anabolic processes. However, the direct involvement of PPP in tumor DNA and RNA synthesis is not considered to be significant, as it is in lipid and protein syntheses (Boros et al., 1998).

Iodoacetic acid (IAA) is reported as a classical inhibitor of anaerobic glycolysis, acting primarily on the enzyme glyceraldehyde-3-phosphate dehydrogenase (G3PDH), which catalyzes the conversion of glyceraldehyde-3-phosphate into the high-energy phosphate compound, 1,3 bisphosphoglycerate with the reduction of $\mathrm{NAD}^{+}$to NADH $\left(\mathrm{H}^{+}\right)$(Bickis and Quastel, 1965). IAA reacts with the sulfhydryl (-SH) group of the cysteine residue at the active site of the enzyme to prevent the formation of thiohemiacetal (Harris, 1992). IAA is also reported to be an inhibitor of glucose6-phosphate dehydrogenase (G6PDH) and 6-phosphogluconate dehydrogenase, the key enzymes of the oxidative segment of PPP (Badwey and Karnovsky,1980). It is reported that the addition of IAA $\left(1 \times 10^{-4}\right.$ M) to ascites tumor cells suspended in 
glucose in air increases the intracellular concentration of fructose diphosphate, which accounts for more than $50 \%$ of the consumed glucose (Wu and Racker, 1958).

Dimethylsulphoxide (DMSO) is a dipolar aprotic solvent that has the ability to cross cellular and vascular membranes with great ease and has been used for administration of compounds that are difficult to solubilize, and thus enhances their effectiveness (Jeffrey and Haschek, 1988). DMSO is a non-enzymatic free oxygen radical detoxifying agent with a high affinity for the hydroxyl radicals, and thus modulates the antioxidant enzyme system of the host (Akyurek et al., 2000). It is known that an increase in the antioxidant enzyme activity could be a mechanism to protect the cells against the hyperproduction of reactive oxygen species by the tumor. Higgins (1986) reported that DMSO, which is a differentiation-inducing agent, has the ability to suppress hepatic tumor cell proliferation by inducing their entrance into the low RNA non-replicating phase (Quiescent phase).

The present study was undertaken to investigate the anti-tumor activities of the single and combined treatments of IAA and DMSO at sub-lethal doses against an experimental non-metastasizing murine tumor model, solid Ehrlich carcinoma, through inhibition of glucose metabolism and provoking the antioxidant defense system in tumor-bearing mice.

\section{MATERIALS AND METHODS}

\section{Tumor}

The initial inoculum of Ehrlich ascites carcinoma (EAC) cells was kindly provided by the National Cancer Institute (Cairo University). EAC cells were thereafter propagated in our laboratory by weekly intra-peritoneal injection of $0.3 \mathrm{ml}$ of $1: 5$ saline solution of freshly drawn ascites fluid from a donor mouse bearing a 6-8 day old ascites tumor. Solid Ehrlich carcinoma was induced by s.c. inoculation of $40 \times 10^{6}$ cells/ $0.25 \mathrm{ml}$ saline in the back between the thighs of each animal (Fahim et al., 1997).

\section{Animals}

Adult female Swiss albino mice weighing $27 \pm 3 \mathrm{~g}$ obtained from the breeding unit of the Egyptian Organization for Biological Products and Vaccines (Cairo) were used in this study. The animals were maintained on a commercial standard pellet diet supplemented with lettuce and carrots and tap water ad libitum.

\section{Chemical compounds}

Iodoacetic acid "sodium salt", (M.W. 209.7, Sigma, U.S.A.) and dimethylsulphoxide (M.W. 78.13 Merck, Germany).

\section{Toxicity studies}

Determination of the acute $\left(\mathrm{LD}_{100}\right)$ and median lethal $\left(\mathrm{LD}_{50}\right)$ doses of IAA was carried out in mice on i.p. administration according to the method of Reed and Muench (1938). The $\mathrm{LD}_{50}$ value of $\mathrm{DMSO}$ was previously reported (Bartasch et al.,1976) to be $1380 \mathrm{mg} / 100 \mathrm{~g} \mathrm{b.w}$. on i.p. administration in mice from which the $\mathrm{LD}_{12.5}$ value was calculated.

\section{Anti-tumor studies}

The anti-tumor activities of IAA and/or DMSO were assessed on 32 mice bearing solid Ehrlich carcinoma that were classified into 4 equally-sized groups (Gr.1-4). Nine days after inoculating the EAC cells (when the tumor became palpable) the animals in Gr.(2-4) were i.p. injected with the $\mathrm{LD}_{12.5}$ values of IAA and/or DMSO every other day for a total of 10 injections, then left untreated until the end of the experiment The animals in Gr.(1) received no treatment and served as a control group. The size of the solid tumor was measured with a Vernier caliper every 4 days and the tumor weight (g) calculated (Geran et al., 1972). The cumulative mean survival time (cMST) of the animals, the tumor growth inhibition ratio $(\mathrm{T} / \mathrm{C} \%)$ and the tumor growth delay time (T-C value), which is based on the 
median time (in days) required for tumors to reach a predetermined size, were also recorded (Bissery et al., 1991).

\section{Biochemical studies}

Sixty mice bearing 9-day-old solid Ehrlich carcinoma were randomly allocated into 4 equally-sized groups as follows: Group II Tumor-bearing controls (Gr.II $\mathrm{T}$ ): the animals received no treatment and served as negative controls. Group III Iodoacetate group (Gr.III IAA): each animal received a single i.p injection of the $\mathrm{LD}_{12.5}$ value of IAA every other day for a total of 10 injections. Group IV Dimethylsulphoxide group (Gr.IV DMSO): each animal was treated every other day with the $\mathrm{LD}_{12.5}$ value of DMSO for 20 days. Group V Combined group (Gr.V Combined): each animal was treated every other day with a mixture of IAA and DMSO (LD 12.5 each) for 20 days. For statistical comparison, a normal control group (Gr.I NC) consisting of 15 normal adult female mice was injected i.p. with sterile saline.

\section{Blood collection and preparation of plasma and blood hemolysates}

At the end of the experimental period (20 days), the animals were sacrificed by decapitation after an overnight fast. Because of the difficulties in obtaining sufficient volumes for the required assays, blood samples pooled from 3 mice were prepared. Plasma samples were stored at $20^{\circ} \mathrm{C}$ in Eppendorf vials for biochemical analysis, while packed red blood cells were immediately washed twice with 20 volumes of phosphate-buffered saline $(\mathrm{pH} 7.4)$ and lysed in $\beta$-mercaptoethanol stabilizing solution (Beulter, 1975).

Tissue sampling and preparation of liver homogenate

The livers from the sacrificed animals were quickly excised, rinsed from blood in isotonic saline and blotted dry with a piece of filter paper. For each specimen a $0.1 \mathrm{~g}$ piece of liver tissue was placed in a test tube containing $2 \mathrm{ml}$ of $30 \%$ potassium hydroxide solution for glycogen determination. Another accurately weighed piece of liver tissue was homogenized in ice-cold saline using a glass homogenizer. The homogenate was then diluted with the homogenization medium to ultimately yield a $10 \%$ (v/v) whole liver homogenate for determination of total protein, RNA and DNA concentrations. All operations were carried out in vessels immersed in an ice bath and dilutions of the stock whole liver homogenate were made as needed.

\section{Biochemical assays}

Levels of plasma glucose (Trinder, 1969) and Lactate dehydrogenase activity (LDH) activity (Allain et al., 1973) were determined using commercial assay kits (Sclavo Diagnostics, and TECO Diagnostics, Italy, respectively). Glutathione peroxidase $\left(\mathrm{GP}_{\mathrm{x}}\right)$ activity (Paglia and Valentine, 1967), Glucose-6phosphate dehydrogenase (G6PDH) activity (Kornberg et al., 1955) and catalase activity (CAT) (Beulter, 1975) were determined in fresh blood hemolysates. Liver glycogen, total protein, RNA and DNA concentrations were also assessed in the diluted whole liver homogenates (Dubois et al., 1956; Markwell et al., 1978; Dische and Schwartz, 1954; and Dische, 1957, respectively).

\section{Statistical analysis}

The statistical significance of the experimental biochemical results was determined by the Student's $t$ test. The statistical significance of the frequency of survivals and cumulative mean survival time of treated animals was determined by the Chi-square test and Logistic $t$ test, respectively (Murray, 1982). For all analyses, $\mathrm{p}<0.05$ was accepted as a significant probability level. 


\section{RESULTS}

Table I shows the anti-tumor activity of IAA and/or DMSO treatments against solid Ehrlich carcinoma in mice. Treatment of tumor-bearing animals with the $\mathrm{LD}_{12.5}$ values of IAA (Gr.2), DMSO (Gr.3) or both compounds (Gr.4) recorded an increase in the life span (ILS \%), which amounted to 145.78, 195.54 and 220.77, respectively, compared to tumor-bearing controls. On day 40 , at which time all tumor-bearing control animals (Gr.1) were dead (MTW $8.75 \pm 1.63 \mathrm{~g}$ ), the mean tumor weights were markedly reduced to $4.92 \pm 0.53,3.39 \pm 1.05$ and $1.89 \pm 0.46 \mathrm{~g}$, and the tumor growth inhibition ratio $(\mathrm{T} / \mathrm{C} \%)$ recorded 43.80 , 61.30 and 78.40 , respectively. The tumor growth delay time was 8,16 and 24 days, respectively.

TABLE I

The anti-tumor activities of IAA and/or DMSO on solid Ehrlich carcinoma compared to tumor-bearing controls.

\begin{tabular}{|c|c|c|c|c|c|c|c|c|}
\hline \multirow[b]{2}{*}{ PTI (days) } & \multicolumn{2}{|c|}{ Gr. 1 (C) } & \multicolumn{2}{|c|}{ Gr. 2 (IAA) } & \multicolumn{2}{|c|}{ Gr. 3 (DMSO) } & \multicolumn{2}{|c|}{ Gr. 4 (Comb.) } \\
\hline & $\mathrm{M}$ & $\mathrm{MTW} \pm \mathrm{SD}$ & M & $\mathrm{MTW} \pm \mathrm{SD}$ & M & $\mathrm{MTW} \pm \mathrm{SD}$ & M & $\mathrm{MTW} \pm \mathrm{SD}$ \\
\hline 9.0 & $0 / 8$ & $0.56 \pm 0.24$ & $0 / 8$ & $0.24 \pm 0.15$ & $0 / 8$ & $0.29 \pm 0.21$ & $0 / 8$ & $0.21 \pm 0.09$ \\
\hline 13 & $0 / 8$ & $1.30 \pm 0.33$ & $0 / 8$ & $0.54 \pm 0.20$ & $0 / 8$ & $0.48 \pm 0.30$ & $0 / 8$ & $0.39 \pm 0.16$ \\
\hline 17 & $0 / 8$ & $2.49 \pm 0.39$ & $0 / 8$ & $0.96 \pm 0.32$ & $0 / 8$ & $0.63 \pm 0.33$ & $0 / 8$ & $0.49 \pm 0.17$ \\
\hline 21 & $0 / 8$ & $4.20 \pm 0.33$ & $0 / 8$ & $1.57 \pm 0.44$ & $0 / 8$ & $0.92 \pm 0.46$ & $0 / 8$ & $0.65 \pm 0.26$ \\
\hline 29 & $0 / 8$ & $6.78 \pm 1.05$ & $0 / 8$ & $2.15 \pm 0.67$ & $0 / 8$ & $1.67 \pm 0.69$ & $0 / 8$ & $0.89 \pm 0.37$ \\
\hline 33 & $1 / 8$ & $7.98 \pm 1.31$ & $0 / 8$ & $3.79 \pm 0.80$ & $0 / 8$ & $2.11 \pm 0.67$ & $0 / 8$ & $1.13 \pm 0.43$ \\
\hline 37 & $6 / 8$ & $8.33 \pm 1.45$ & $0 / 8$ & $4.12 \pm 0.46$ & $0 / 8$ & $2.68 \pm 0.83$ & $0 / 8$ & $1.49 \pm 0.42$ \\
\hline 40 & $8 / 8$ & $8.75 \pm 1.63$ & $0 / 8$ & $4.92 \pm 0.53$ & $0 / 8$ & $3.39 \pm 1.05$ & $0 / 8$ & $1.89 \pm 0.46$ \\
\hline 43 & & & $0 / 8$ & $5.12 \pm 0.63$ & $0 / 8$ & $4.09 \pm 1.25$ & $0 / 8$ & $2.31 \pm 0.51$ \\
\hline 49 & & & $1 / 8$ & $6.31 \pm 0.92$ & $0 / 8$ & $4.97 \pm 1.10$ & $0 / 8$ & $3.05 \pm 0.67$ \\
\hline 55 & & & $5 / 8$ & $7.11 \pm 0.77$ & $0 / 8$ & $5.84 \pm 1.05$ & $0 / 8$ & $4.05 \pm 1.11$ \\
\hline 57 & & & $8 / 8$ & $7.50 \pm 0.57$ & $0 / 8$ & $6.38 \pm 1.25$ & $0 / 8$ & $4.51 \pm 1.08$ \\
\hline 60 & & & & & $0 / 8$ & $6.92 \pm 1.05$ & $0 / 8$ & $4.96 \pm 0.96$ \\
\hline 66 & & & & & $1 / 8$ & $7.90 \pm 0.78$ & $0 / 8$ & $5.91 \pm 0.98$ \\
\hline 72 & & & & & $5 / 8$ & $7.99 \pm 0.97$ & $0 / 8$ & $6.86 \pm 0.97$ \\
\hline 74 & & & & & $8 / 8$ & $8.03 \pm 0.57$ & $0 / 8$ & $7.09 \pm 0.88$ \\
\hline 78 & & & & & & & $3 / 8$ & $7.21 \pm 1.01$ \\
\hline 82 & & & & & & & $8 / 8$ & $7.35 \pm 0.64$ \\
\hline MST (days) & & 35.67 & & 52 & & 69.75 & & 78.75 \\
\hline ILS (\%) & & - & & 145.78 & & 195.54 & & 220.77 \\
\hline $\mathrm{T} / \mathrm{C}(\%)$ & & - & & 43.80 & & 61.30 & & 78.40 \\
\hline T-C (days) & & - & & 8 & & 16 & & 24 \\
\hline
\end{tabular}

MST $=$ mean survival time

Increase of life span $(\mathrm{ILS} \%)=\frac{\text { mean survival time of test }}{\text { mean survival time of control }} \times 100$

Tumor inhibition ratio $(\mathrm{T} / \mathrm{C} \%)=\frac{\text { mean tumor weigth of control }- \text { mean tumor weight of test }}{\mathrm{N}} 100$

$(\mathrm{T}-\mathrm{C})$ value $=$ tumor growth de lay time

$\mathrm{PTI}=$ post tumor inoculation

$\mathrm{M}=$ mortality

MTW $=$ Mean tumor weigth 
Table II illustrates the statistical significance of the percentage of survivors and the cumulative mean survival time (cMST) of tumor-bearing mice treated with IAA (Gr.2), DMSO (Gr.3) or combined agents (Gr.4), compared to tumor-bearing controls. On day 40, the percentage of survivors was $100 \%(\mathrm{p}<0.001)$ in all treated groups (Gr.2\&3\&4), whereas on day 57, when all of the Gr.(2) animals were completely depleted, the percentage of survivors in Gr. (3\&4) was $100 \%$ $(p<0.001)$. On day 74 , at which time all of the Gr. (3) animals were dead, the percentage of survivors in Gr.(4) was $100 \%$ $(\mathrm{p}<0.001)$. A highly significant increase of $43.61,85.30$ and $109.78 \%(\mathrm{p}<0.001)$ was recorded in the cMST of Gr.(2, 3, \& 4), respectively, compared to Gr.(1). Also, an increase of 29 and $46.07 \%(\mathrm{p}<0.001)$ was recorded in the cMST of Gr.(3\&4), respectively, compared to Gr.(2), while it was only $13.24 \%(\mathrm{p}<0.05)$ in Gr.(4) compared to Gr.(3).

Table III shows the changes in some blood and liver analytes in tumor-bearing mice treated with IAA and/or DMSO.
Significant elevations were recorded in the levels of plasma LDH $(195.47 \%, \mathrm{p}<0.001)$, erythrocytes $\mathrm{GP}_{\mathrm{x}}(69.98 \%, \mathrm{p}<0.001)$, G6PDH $(46.63 \%, \mathrm{p}<0.001)$ and CAT activities $(28.60 \%, \mathrm{p}<0.05)$, with a concomitant reduction in the plasma glucose level $(51.36 \%, \mathrm{p}<0.001)$ of tumorbearing animals (Gr.II T), compared to normal controls (Gr.I NC). Treatment of tumor-bearing animals with 10 injections of IAA (Gr. III) produced significant decreases in the levels of plasma glucose $(23.05 \%, \mathrm{p}<0.01)$, erythrocytes $\mathrm{GP}_{\mathrm{x}}$ (26.74\%, $\mathrm{p}<0.01)$, and G6PDH activities $(22.78 \%, \mathrm{p}<0.05)$ associated with a significant increase in the level of plasma LDH activity $(41.10 \%, \mathrm{p}<0.01)$, compared to normal controls. Treatment with 10 injections of DMSO (Gr.IV) increased significantly the activities of erythrocytes $\mathrm{GP}_{\mathrm{x}}$ and G6PDH (17.65\%, $\mathrm{p}<0.05$ and $114.65 \%, \mathrm{p}<0.001$, respectively), while the levels of plasma glucose and LDH activity were not significantly changed. Combined treatment of tumor-bearing animals (Gr.V) gave rise to significant elevations in the levels of plasma LDH $(37.63 \%, \mathrm{p}<0.01)$

\section{TABLE II}

Effect of IAA and/or DMSO on the frequency of survivors and the cumulative mean survival time of tumor-bearing animals compared to tumor-bearing controls.

\begin{tabular}{|c|c|c|c|c|c|c|}
\hline \multirow[b]{2}{*}{ Groups } & \multicolumn{3}{|c|}{ Frequency of Survivors ${ }^{a}$} & \multicolumn{3}{|c|}{ Cumulative Survival Time } \\
\hline & $\begin{array}{c}\text { Survivors } \\
\mathrm{n}(\%)\end{array}$ & $\begin{array}{c}\text { Deaths } \\
\mathrm{n}(\%)\end{array}$ & $\mathrm{P}^{\mathrm{b}}<$ & $\begin{array}{l}\text { Means } \pm \text { SD } \\
\quad \text { (days) }\end{array}$ & Change $\%$ & $\mathrm{P}^{\mathrm{c}}<$ \\
\hline \multicolumn{7}{|l|}{ On day 40} \\
\hline Gr.1 (T) & $0(0)$ & $8(0)$ & - & $20.75 \pm 8.92$ & - & - \\
\hline Gr.2 (IAA) & $8(100)$ & $0(0)$ & 0.001 & $29.80 \pm 13.54$ & 43.61 & 0.001 \\
\hline Gr.3 (DMSO) & $8(100)$ & $0(0)$ & 0.001 & $38.44 \pm 18.24$ & 85.30 & 0.001 \\
\hline Gr.4 (Comb.) & $8(100)$ & $0(0)$ & 0.001 & $43.53 \pm 21.05$ & 109.78 & 0.001 \\
\hline \multicolumn{7}{|l|}{ On day 57} \\
\hline Gr.2 (IAA) & $0(0)$ & $8(0)$ & - & $29.80 \pm 13.54$ & - & - \\
\hline Gr.3 (DMSO) & $8(100)$ & $0(0)$ & 0.001 & $38.44 \pm 18.24$ & 29.00 & 0.001 \\
\hline Gr.4 (Comb.) & $8(100)$ & $0(0)$ & 0.001 & $43.53 \pm 21.05$ & 46.07 & 0.001 \\
\hline \multicolumn{7}{|l|}{ On day 74} \\
\hline Gr.3 (DMSO) & $0(0)$ & $8(0)$ & 0.001 & $38.44 \pm 18.24$ & - & - \\
\hline Gr.4 (Comb.) & $8(100)$ & $0(0)$ & 0.001 & $43.53 \pm 21.05$ & 13.24 & 0.05 \\
\hline
\end{tabular}

\footnotetext{
(a) Percentage of survivors on day 40, 57, and 74 post tumor inoculation.

(b) Probability value was obtained by use of Chi-square analysis.

(c) Probability value was obtained by use of logistic t-test.
} 
TABLE III

Effects of IAA and/or DMSO (10 injections) on the levels of plasma glucose, lactate dehydrogenase and erythrocytes glutathione peroxidase $\left(\mathrm{GP}_{\mathrm{x}}\right)$, glucose-6-phosphate dehydrogenase (G6PDH) and catalase (CAT) activities and hepatic total protein, RNA and DNA contents in tumor-bearing animals compared to normal controls.

\begin{tabular}{|c|c|c|c|c|c|c|c|c|c|}
\hline \multirow[b]{2}{*}{ Groups } & \multicolumn{2}{|c|}{ Plasma $^{\mathrm{a}}$} & \multicolumn{3}{|c|}{ Erythrocytes ${ }^{\mathrm{a}}$} & \multicolumn{4}{|c|}{ Liver $^{b}$} \\
\hline & $\begin{array}{c}\text { Glucose } \\
\mathrm{mg} / \mathrm{dl}\end{array}$ & $\begin{array}{l}\text { LDH } \\
\text { IU/L }\end{array}$ & $\begin{array}{c}\mathrm{GP}_{\mathrm{x}} \\
\mathrm{U} / \mathrm{g} \mathrm{Hb}\end{array}$ & $\begin{array}{l}\text { G6PDH } \\
\text { U/g Hb }\end{array}$ & $\begin{array}{c}\text { CAT } \\
\mathrm{K} / \mathrm{g} \mathrm{Hb}\end{array}$ & $\begin{array}{l}\text { Glycogen } \\
\mathrm{mg} / \mathrm{g} \text { tissue }\end{array}$ & $\begin{array}{l}\text { T. Protein } \\
\mathrm{mg} / \mathrm{g} \text { tissue }\end{array}$ & $\begin{array}{c}\text { RNA } \\
\mathrm{mg} / \mathrm{g} \text { tissue }\end{array}$ & $\begin{array}{c}\text { DNA } \\
\mathrm{mg} / \mathrm{g} \text { tissue }\end{array}$ \\
\hline \multicolumn{10}{|l|}{ Gr.I NC } \\
\hline Mean \pm SD & $114.10 \pm 11.9$ & $1964 \pm 138.2$ & $130.9 \pm 13.1$ & $9.35 \pm 0.63$ & $175.6 \pm 34.6$ & $13.84 \pm 1.68$ & $197.1 \pm 10.32$ & $10.19 \pm 1.28$ & $3.95 \pm 0.49$ \\
\hline \multicolumn{10}{|l|}{ Gr. II T } \\
\hline Mean \pm SD & $55.5 \pm 7.0$ & $5803 \pm 610$ & $222.5 \pm 18.2$ & $13.71 \pm 1.39$ & $225.8 \pm 29.4$ & $8.34 \pm 1.94$ & $184.50 \pm 20.6$ & $11.94 \pm 0.86$ & $4.5 \pm 0.69$ \\
\hline Change $\%$ & -51.36 & 195.47 & 69.98 & 46.63 & 28.60 & -39.74 & -6.40 & 17.17 & 13.92 \\
\hline $\mathrm{P}<$ & 0.001 & 0.001 & 0.001 & 0.001 & 0.05 & 0.001 & N.S. & 0.01 & N.S. \\
\hline \multicolumn{10}{|l|}{ Gr. III IAA } \\
\hline Mean \pm SD & $87.8 \pm 4.9$ & $2771 \pm 396$ & $95.9 \pm 16.9$ & $7.22 \pm 1.58$ & $204.8 \pm 21.5$ & $14.56 \pm 3.21$ & $169.1 \pm 12.3$ & $19.0 \pm 1.06$ & $3.19 \pm 0.75$ \\
\hline Change $\%$ & -23.05 & 41.10 & -26.74 & -22.78 & 16.63 & 5.20 & -14.20 & -11.70 & -19.24 \\
\hline $\mathrm{P}<$ & 0.01 & 0.01 & 0.01 & 0.05 & N.S. & N.S. & 0.00 & 0.05 & 0.02 \\
\hline \multicolumn{10}{|l|}{ GrIVDMSO } \\
\hline Mean \pm SD & $118.0 \pm 19.7$ & $2068 \pm 210$ & $154.0 \pm 15.4$ & $20.06 \pm 0.73$ & $199.6 \pm 15.3$ & $16.42 \pm 4.25$ & $211.6 \pm 12.9$ & $9.14 \pm 0.93$ & $2.97 \pm 1.14$ \\
\hline Change $\%$ & 3.42 & 5.30 & 17.65 & 114.65 & 13.67 & 18.64 & 7.36 & -10.30 & -24.81 \\
\hline $\mathrm{P}<$ & N.S. & N.S. & 0.05 & 0.001 & N.S. & N.S. & 0.02 & 0.05 & 0.05 \\
\hline \multicolumn{10}{|l|}{ Gr. V Comb. } \\
\hline MeantSD & $105.9 \pm 11.4$ & $2703 \pm 433$ & $120.9 \pm 20.2$ & $14.79 \pm 0.70$ & $186.0 \pm 12.4$ & $19.79 \pm 5.614$ & $164.2 \pm 11.5$ & $8.19 \pm 1.50$ & $3.19 \pm 0.61$ \\
\hline Change $\%$ & -7.18 & 37.63 & -7.64 & 58.18 & 5.92 & 43 & -16.70 & -19.63 & -19.24 \\
\hline $\mathrm{P}<$ & N.S. & 0.01 & N.S. & 0.001 & N.S. & 0.01 & 0.001 & 0.01 & 0.01 \\
\hline
\end{tabular}

${ }^{a}$ Results are means $\pm S D$ of 5 values, each consisted of 3 pooled mice

${ }^{\mathrm{b}}$ Results are means \pm SD of 10 mice

and erythrocytes G6PDH activities $(58.18 \%, \mathrm{p}<0.001)$. The level of erythrocyte CAT activity was not significantly affected in all treated groups. In connection to liver parameters a significant reduction in glycogen concentration (39.74\%, $\mathrm{p}<0.001)$, a significant increase in RNA concentration $(17.17 \%, \mathrm{p}<0.01)$ and a nonsignificant change in the levels of total protein and DNA were recorded in tumorbearing animals (Gr. II), compared to normal controls. Treatment of tumorbearing animals with 10 injections of IAA (Gr.III) produced significant decreases in total protein $(14.20 \%, \mathrm{p}<0.01)$, RNA $(11.70 \%, \mathrm{p}<0.05)$ and DNA $(19.24 \%$, $\mathrm{p}<0.02)$ concentrations, whereas hepatic glycogen concentration was not significantly changed, compared to normal controls. Treatment with 10 injections of DMSO (Gr. IV) showed a significant elevation in total protein concentration $(7.36 \%, p<0.02)$, and in contrast a significant reduction in RNA and DNA concentrations (10.30 and $24.81 \%, \mathrm{p}<0.05$, respectively). Combined treatment (Gr.V) caused a significant elevation in glycogen concentration $(43 \%, \quad p<0.01)$ and significant decreases in total protein (16.70\%, p<0.001), RNA and DNA concentrations (19.63 and $19.24 \%, \mathrm{p}<0.01$, respectively) compared to normal controls.

\section{DISCUSSION}

In the present study, the acute $\mathrm{LD}_{100}$ and $\mathrm{LD}_{50}$ values of IAA on i.p administration 
are reported to be 11.59 and $7.35 \mathrm{mg} / 100 \mathrm{~g}$ b.w. respectively in adult female Swiss albino mice. Treatment of tumor-bearing mice with the $\mathrm{LD}_{12.5}$ values of IAA (1.84 $\mathrm{mg} / 100 \mathrm{~g} \mathrm{b.w.})$ and DMSO (350 mg/100 g b.w.) exerted a significant effect in the retardation of the tumor growth. This is demonstrated by significant increases in the percentage of survivors and the cumulative mean survival time on day $40(\mathrm{p}<0.001)$, compared to tumor-bearing controls, and the marked decrease in the mean tumor weights. It merits note that a more pronounced effect was observed in the combined treatment represented by higher increases in the life span of animals $(220.77 \%)$ and the tumor inhibition ratio $(78.40 \%)$, compared to tumor-bearing controls, in addition to higher increases in the percentage of survivors and the cMST, compared to single IAA and DMSO treatments (Tables I and II). Our findings are in line with the main concept of cancer research that evaluation of any tested substance depends on extension of the survival time of cancer patients, and that an increase in the life span of drug -treated tumor-bearing mice $\geq 125 \%$ is considered indicative of presumptive drug activity (Rose et al., 1984 and Buc-Calderon et al., 1989) .

Biochemical studies were carried out to assess the effects of the metabolic inhibitor IAA and the free radical scavenger DMSO on the glucose metabolism and the antioxidant defense system of tumorbearing animals and, in turn, their involvement in retardation of the tumor growth. Hypoglycemia and depleted liver glycogen content, which were previously reported in tumor-bearing animals (Balint, 1991; Killington et al., 1991; Rawall et al., 1991; and Fahim et al., 1993), are greatly modulated by IAA treatment. This observation could be explained in terms of the IAA inhibitory effects on the anaerobic glycolysis (Bickis and Quastel, 1965), the pentose phosphate pathway (Badwey and Karnovsky, 1980) and the glycogen phosphorylase activity (Takeuchi and Glenner, 1961). The amelioration of the plasma glucose level and the significant increase in the liver glycogen concentration in the combined group could be ascribed primarily to the ability of the polar solvent DMSO to cross cell membranes and thus potentiate the hyperglycemic effect of IAA. This indicates that IAA and DMSO act synergistically to suppress the growth of solid tumor by depriving the cancer cells of the energy fuels, and by decreasing the pentose pool necessary for DNA and RNA syntheses in rapidly proliferating cells.

Results presented in Table III demonstrate a significant elevation in the levels of erythrocytes $\mathrm{GP}_{x}, \mathrm{G6PDH}$ and CAT activity after 29 days of tumor implantation. Our results are in accordance with those of Navarro et al. (1999), who affirmed significant elevations in erythrocytes $\mathrm{GP}_{\mathrm{x}}$, G6PDH and CAT activities in mice bearing growing Ehrlich ascites tumor cells, which confirms the oxidative stress on the host in response to the continual generation of free oxygen radicals by the increasing tumor load. Treatment with 10 injections of IAA caused significant reductions in erythrocytes $\mathrm{GP}_{\mathrm{x}}$ and $\mathrm{G6PDH}$ activities, and a nonsignificant change in the level of erythrocyte CAT activity, compared to normal controls (Table III). The biochemistry of the erythrocyte is relatively simple, with its metabolism dependent primarily on glycolysis and the PPP. The first oxygen free radical to be generated is the superoxide anion $\left({ }^{\bullet} \mathrm{O}_{2}^{-}\right)$, which is responsible for the formation of the subsequent oxygen free radicals by dismutation into $\mathrm{H}_{2} \mathrm{O}_{2}$, which is detoxified by catalase or transformed into - OH radical by Fenton's reaction (Burrell and Blake, 1989). IAA is also known as a sulfhydryl inhibitor, i.e. an electrophile that inhibits the G3PDH enzyme by conjugation with the (-SH) group essential for the enzyme activity. However, other thiols, such as glutathione, also react with IAA at high concentrations causing depletion of the intracellular pool of glutathione (Nicotera and Orrenius, 1986). Taken together, the significant reduction in blood $\mathrm{GP}_{\mathrm{x}}$ and G6PDH by IAA treatment could be infered.

In contrast, DMSO treatment resulted in a significantly sharp increase in the erythrocytes G6PDH activity and a slight increase in $\mathrm{GP}_{\mathrm{x}}$ activity, while the erythrocyte CAT activity was not significantly changed, compared to normal 
controls (Table III). Our results are in line with those of Ahmed et al. (1993), who reported that DMSO increases the activity of the oxidative segment of the PPP by two-fold, and the activity of two NADPHproducing enzymes; G6PDH and 6phosphogluconate dehydrogenase by 3-6 fold in human promyelocytic leukemic cell line HL60. It has also been reported that DMSO could protect biological systems from the damaging effects of free radicals by its capacity to be oxidized (McGregor, 1967). Protection against free radicals and peroxides is largely dependent upon the availability of reduced glutathione (GSH), which in turn requires NADPH for its continual regeneration (Gessner et al., 1990). Taken together, together, it could be interpreted that the significant elevations in erythrocytes $\mathrm{GP}_{\mathrm{x}}$ and $\mathrm{G6PDH}$ activity provide a greater protection against the induced tumor. In the combined group, the counteracting effects of IAA and DMSO could account for the insignificant variations in the activity of blood $\mathrm{GP}_{\mathrm{x}}$ and CAT enzymes. However, the persistent increase in blood G6PDH activity could be ascribed to the direct effect of DMSO on the oxidative segment of the PPP.

Untreated tumor-bearing mice (Gr.IIT) showed non-significant changes in the hepatic total protein and DNA concentrations associated with a significant elevation in the hepatic RNA concentration after 4 weeks, compared to normal controls (Table III). Comparable results were previously reported and explained (Lundholm et al., 1978, 1979; Bengtsson and Andersson, 1981; and Ternell et al., 1985). The significant decreases in the levels of hepatic total protein, RNA and DNA in response to IAA treatment are in accordance with the findings of Glazer and Weber (1971), who reported a significant reduction in the total protein, RNA and DNA synthesis of newborn rat brain cortex slices after the addition of IAA due to one site of action for IAA on DNA synthesis, which may involve some processes concerned with the formation of DNA precursors, such as the sulfhydryl-sensitive ribonucleotide reductase complex. Another explanation for this observation was documented by Kosower and Kosower (1978) that IAA conjugates with the $-\mathrm{SH}$ group of glutathione, which has been postulated as a potential regulator for protein synthesis, DNA synthesis and cell proliferation. This suggestion is in line_with our findings and accounts for the significant decreases in the levels of erythrocytes $\mathrm{GP}_{\mathrm{x}}$ and G6PDH activity (Table III).

On the other hand, treatment with 10 injections of DMSO (Gr.IV) significantly decreased the hepatic RNA and DNA concentrations, and in contrast, increased the level of hepatic total protein (Table III). Our data are in agreement with the results obtained from the in vitro studies of Higgins and Donnell (1982) and Higgins (1984), who tested the effect of the differentiation-inducing agent (DMSO) on the protein composition of murine hepatic tumor cell line (BW 77-1) and found that DMSO increased total cellular protein, especially the albumin and transferrin fractions. In addition, Higgins (1986) affirmed that suppression of murine liver tumor cells (BW 77-2 and Hepa-1/A1) proliferation by $3 \%$ DMSO $(0.26 \mathrm{~g} / 100 \mathrm{~g}$ b.w.) persists only in the continuous exposure assay and that resumption of cell division is readily observed following the removal of DMSO from the culture medium. During DMSO treatment, $88 \%$ of the tumor cells were accumulated in the $\mathrm{G}_{1}$ phase of the cell cycle, compared to $48 \%$ of $\mathrm{G}_{1}$ cells in the control cultures, and exhibited a substantial shift to lower mean cellular RNA content. Low RNA, nonreplicating hepatic tumor cells in DMSOtreated cultures were designated as being in the "Q ${ }_{i}$ " substate (Quiescent phase). Accordingly, this points to the importance of the continuous exposure of DMSO in the tumor treatment, which accounts for the partial suppression of cell proliferation in the intermittent treatment modality implemented in the present study due to incomplete cell arrest in the quiescent substate. The more notable reduction in the liver total protein concentration in response to the combined treatment (Gr.V) might be due to the IAA and DMSO synergism (Table III). 


\section{CONCLUSIONS}

In conclusion, treatment with IAA or DMSO significantly retards the growth of solid Ehrlich carcinoma, which is more pronounced in the combined treatment modality demonstrated by the higher increase in the cumulative mean survival time, tumor growth inhibition ratio, and the highest reduction in the mean tumor weight, compared to tumor-bearing controls. Results obtained from this study suggest that the retardation of the tumor growth rate by IAA and DMSO takes place by two different modes of action. The IAA inhibits the main pathways of energy production, i.e. glycolysis, pentose monophosphate pathways and glycogenolysis. On the other hand, DMSO suppresses the tumor growth not only by arresting the tumor cells in the quiescent phase as previously reported, but also by inducing the host defense system through the induction of the antioxidant enzyme system to increase the disposal of overproduced reactive free oxygen radicals. This suggests that IAA and DMSO could be used as adjuncts to chemotherapy or surgery for the management of cancer.

\section{REFERENCES}

AHMED N, WILLIAMS JF, WEIDMANN MJ (1993) Glycolytic, glutaminolytic and pentose-phosphate pathways in promyelocytic HL60 and DMSOdifferentiated HL60 cells. Biochem Mol Biol Int 29 (6): 1055-1067

AKYUREK N, KAFALI EM, MUHTAROGLU S (2000) The effect of dimethylsulphoxide on experimental hepatic ischemia. Swiss Surg 6: 23-27

ALLAIN CC, HENSON CP, NADEL MK, KNOBLESDORFF AJ (1973) Rapid single-step kinetic colorimetric assay for lactate dehydrogenase in serum. Clin Chem 19: 223-227

BADWEY JA, KARNOVSKY MI (1980) Active oxygen species and the function of phagocytic leukocytes. Ann Rev Biochem 49: 695-726

BALINT Z (1991) Lipolytic activity in adipose tissue of mice bearing Ehrlich ascites carcinoma. Cancer Biochem Biophys 12: 45-50

BARTSCH W, SPONER K, FUCHS G (1976) Acute toxicity of various solvents in the mouse and rat. Arzeneim-Forsch 26(8): 1581-1583

BENGTSSON G, ANDERSSON G (1981)The effect of Ehrlich ascites tumor growth on lactate dehydrogenase activities in tissues and physiological fluids of tumorbearing mice. Int J Biochem 13 (1): 53-61

BEULTER E (1975) Red Cell Metabolism: A manual of biochemical methods. New York: Grune \& Stratton, Inc.
BICKIS IJ, QUASTEL JH (1965) Effects of metabolic inhibitors on energy metabolism of Ehrlich ascites carcinoma cells. Nature 205 (2): 44-46

BISSERY MC, GUENARD D, GUERITTE-VOGELLIEN F, LAVELLE F (1991) Experimental Anti-tumor activity of taxotera, a total analog. Cancer Res 51: 4845-4850

BOROS LG, LEE PW, BRANDES JL, CASCANTE M, MUSCARELLA P, SCHHIMER WJ, MELVIN WS, ELLISON EC (1998) Non-oxidative pentose phosphate pathways and their direct role in ribose synthesis in tumors: Is cancer a disease of cellular glucose metabolism? Med Hypotheses 50: 55-59

BUC-CALDERÓN P, PRAET M, RUYSSCHAERT JM, ROBERFROID M (1989) Increasing therapeutic effect and reducing toxicity of doxorubicin by $\mathrm{N}$ acyldehydroalanines. Eur J Cancer Clin Oncol 25: 679-687

BURREL CJ, BLAKE DR (1989) Reactive oxygen metabolites and the human myocardium. Br Heart J 61: 4-8

DISCHE Z (1957) Determination of pentoses. In: COLOURICK $\mathrm{S} P$ and KAPLAN NO (eds) Methods in Enzymology. Vol. III. New York: Academic Press Inc p: 88

DISCHE Z, SCHWARTZ K (1954) Estimation of nucleic acids. In: GLICK D (ed). Methods of Biochemical analysis. Vol. I. New York: Interscience Publishers Inc. p: 299

DUBOIS M, GILLES KA, HAMILTON LK, REBUS PA (1956) Colorimetric method for determination of sugar and related substances. Anal Chem 28: 350-358

FAHIM FA, ABDALLAH NM, ESMAT AY (1993) Some metabolic aspects in normal and tumor bearing mice treated with a natural anthraquinone. J Tumour Marker Oncol 8: 35-44

FAHIM FA, ESMAT AY, MADY EA, AMIN MA (1997) Serum LDH and ALP isozyme activities in mice bearing solid Ehrlich carcinoma and/or treated with the maximum tolerated dose (MTD) of aloin. Disease Markers 13: 183-193

GERAN RT, GREENBERG NH, MACDONALD MM, SCHUMACHER AM (1972) Protocols of screening chemical agents and natural products against animal tumors and other biological systems. Cancer Chemother Rep 3 (3): 1-7

GESSNER T, VAUGHAN LA, BEEHLER BC, BARTELS CJ, BAKER RM (1990) Elevated pentose cycle and glucuronyltransferase in daunorubicin resistant P388 cells. Cancer Res 50 (13): 3921-3927

GLAZER RI, WEBER G (1971) Iodoacetate inhibition of lactate production and lipid, protein, ribonucleic acid (RNA) and deoxyribonucleic acid (DNA) synthesis in newborn rat brain cortex slices. Biochem Pharmacol 20: $2121-2123$

HARRIS RA (1992) Carbohydrate metabolism: Textbook of Biochemistry, Chap 7, $4^{\text {th }}$ ed., DEVLIN TM (ed), New York: Wiley-Liss Inc. pp: 293-294.

HIGGINS PJ (1984) Protein accumulation in cultures of hepatic tumor cells exposed to dimethylsulphoxide. Oncol 41: 338-342

HIGGINS PJ (1986) Characterization of the growth inhibited substate induced in murine hepatic tumor cells during in vitro exposure to dimethylsulphoxide. Int J Cancer 38 (6): 889-899

HIGGINS PJ, DONNELL PV (1982) Dimethylsulphoxideinduced alterations in the growth properties and protein composition of in vitro-propagated murine hepatoma cells. Oncology 39: 325-330

JEFFREY EH, HASCHEK WM (1988) Protection by dimethylsulphoxide against acetominophen-induced hepatic, but not respiratory toxicity in the mouse. Toxicol Appl Pharmacol 93 (3): 452-461 
KAIRENTO AL，BROWNELL，GL， ELMALEH，DR, SWARTZ, M. R (1985) Comparative measurement of regional blood flow, oxygen and glucose utilization in soft tissue tumor of rabbit with positron imaging. Br J Radiol 58: 637-643

KILLINGTON RA, WILLIAMS AE, RATCHFFE NA, WHITEHEAD TP (1991) Hypoglycemia in rats bearing ascites tumor. Br J Cancer 25:93-98

KORNBERG A, HORECKER BL, KAPLAN NO (1955) Methods in Enzymology. Vol. I. New York: Academic Press. p: 323

KOSOWER NS, KOSOWER EM (1978)The glutathione status of cells. Int Rev Cytol 54: 109-159

LUNDHOLM K, EDSTROM S, EKMAN L, KARLBERG I, BYLUND AC, SCHERSTEN T (1978) A comparative study of the influence of malignant tumor on host metabolism in mice and man. Cancer 42: 453-461

LUNDHOLM K, EKMAN L, EDSTROM S, KARLBERG I, JAGENBURG R, SCHERSTEN T (1979) Protein synthesis in liver tissue under the influence of a methylcholanthrene-induced sarcoma in mice. Cancer Res 39: 657-661

MARKWELL KM, HASS SM, BERBER LL,TOLBERT NE (1978) A modification of the Lowry procedure to simplify protein determination in membrane and lipoprotein samples. Anal Biochem 87: 206-211

MCGREGOR WJ (1967)The chemical and physical properties of DMSO. Ann NY Acad Sci 141:3-12.

MURRAY RS (1982) In: Schaum's Outlines Series of Theory and Problems of Probability and Statistics. Singapore: McGraw-Hill Book Co

NAVARRO J, OBRADOR E, CARRETERO J, PETSCHEN I, AVINO J, PÉREZ P, ESTRELA JM (1999) Changes in glutathione status and the antioxidant system in blood and in cancer cells associate with tumor growth in vivo. Free Rad Biol Med 26: 410-418

NICOTERA P, ORRENIUS S (1986) Role of thiols in protection against biological reactive intermediates. Adv Exp Med Biol 197: 41-51

PAGLIA DE, VALENTINE WN (1967) Studies on the quantitative and qualitative characterization of erythrocyte glutathione peroxidase. J Lab Clin Med 70 (1): 158-169

SUTHANTHIRAN M, ANDERSON ME, SHARMA VK, MEISTER A (1990) Glutathione regulates activationdependent DNA synthesis in highly purified normal human T-lymphocytes stimulated via the CD2 and CD3 antigens. Proc Natl Acad Sci 87 (9): 3343-3347

RAWALL A, ALVOUES FL, NORDI RC (1991) Regulation of carbohydrate formation and utilization by animal bearing tumors. J Biol Chem 258: 3404-3409

REED LH, MUENCH H (1938) A simple method of estimating fifty percent point. Am J Hyg 37: 493-501

ROSE W, REED F, SIMINOFF P, BRADNER W (1984) Immunotherapy of Madison 109 lung carcinoma using lentinan. Cancer Res 44:1368-1372

TAKEUCHI T, GLENNER GG (1961) Histochemical demonstration of uridine-diphosphate glucoseglycogen transferase in animal tissues. J. Histochem Cytochem 9: 304-316

TERNELL M, LONNROTH C, MOLDAWER LL, GELIN J, LUNDHOLM K (1985) Plasma protein synthesis in experimental cancer compared to paraneoplastic conditions, including monokine administration. Cancer Res 47: 5825-5830

TRINDER P (1969) Determination of glucose in blood using glucose oxidase with an alternative oxygen acceptor. Ann Clin Biochem 6: 24-28

WU R, RACKER E (1958) Regulatory mechanisms in carbohydrate metabolism. J Biol Chem 234: 1029-1031. 